\title{
Psychological capital and performance among undergraduate students: the role of meaning-focused coping and satisfaction
}

\author{
Alberto Ortega-Maldonado \\ Marisa Salanova
}

WANT Research Team, Universitat Jaume I de Castellón, Castellón de la Plana, Spain

\begin{abstract}
Alberto Ortega-Maldonado (Corresponding author). Universitat Jaume I de Castellón, Departamento de Psicología Evolutiva, Educativa, Social y Metodología. Av. de Vicent Sos Baynat, s/n, 12071, Castellón de la Plana: Castellón (Spain).

email: aortega@uji.es / Phone: +34 964729569
\end{abstract}

ORCiD: orcid.org/0000-0003-0306-2963

LinkedIn: https://es.linkedin.com/in/alberto-ortega-maldonado-186a2757

Marisa Salanova. Universitat Jaume I de Castellón, Departamento de Psicología Evolutiva, Educativa, Social y Metodología. Av. de Vicent Sos Baynat, s/n, 12071, Castellón de la Plana: Castellón (Spain).

email: salanova@uji.es / Phone: +34 964729583

ORCiD: orcid.org/0000-0001-7873-7078

LinkedIn: https://es.linkedin.com/in/marisasalanova

Alberto Ortega-Maldonado is a PhD student at the Universitat Jaume I of Castellón, Spain. He is conducting his doctoral thesis on how to increase well-being in academic and work organizations through positive interventions. He is very interested in the scientific dissemination in order to improve the evidence-based management.

Marisa Salanova is a full professor in Positive Organizational Psychology at the Universitat Jaume I of Castellón, Spain. She is also the Director of WANT-Research Team High Performance Group. Currently she is the salient President of the Spanish Society of Positive Psychology (SEPP) and she is an Advisor of the International Positive Psychology Association (IPPA) Work and Organizations Division's. She has about 300 national and international publications on Occupational Health Psychology and Positive Psychology applied to work. She has created a project of dissemination to share scientific knowledge and to help people and organizations to live a more fulfilling and meaningful life and be happier. 


\section{Psychological capital and performance among undergraduate students: the role of meaning-focused coping and satisfaction}

This study explores the predictive relationships between psychological capital (PsyCap), meaning-focused coping, satisfaction and performance among undergraduate students. Six hundred and eighty two $(n=682)$ college students from 29 different academic programs completed an academic well-being survey, which included measures of PsyCap, coping strategies, and academic satisfaction (time 1). Performance data was collected five months later (time 2), at the end of the year. Path analysis results provided support for a sequential mediation model where PsyCap was directly related to performance, and indirectly related to performance through meaning-focus coping and satisfaction. In addition, PsyCap was directly associated with satisfaction, highlighting the importance of this psychological construct in academic settings. Understanding the role that meaning-focused coping and satisfaction play in the relationship between psychological capital and performance may be useful for scholars and lecturers to design optimal evidenced-based interventions to increase both well-being and academic achievement.

Keywords: psychological capital, meaning-focused coping, satisfaction, performance.

Academic performance is one of the most relevant outcomes in the university setting. It refers to the knowledge that students have acquired at the end of a university program. Excellence in academic performance refers to high levels of theoretical, practical and technical knowledge. Academic performance and learning are proposed to influence individual's career success and employability (Fugate, Kinicki, \& Ashforth, 2004). For that reason, improving performance has become a central issue of the universities' political agenda. According to Siu, Bakker, and Jiang, (2014) university students need to meet current social and economy challenges and to find their competitive advantage. For that reason it is necessary to motivate students to obtain high levels in academic performance. Institutional programs are designed by universities to identify factors that 
influence higher performance on undergraduate studies. Deeper research on this field is necessary to develop evidence-based interventions to improve students' performance and learning (Lane, Hall, \& Lane, 2004). The present study aims to contribute to fill the gap in the academic performance literature, exploring the paths and relationships between academic performance and its psychological predictors.

\section{Psychological capital and performance}

A variable proposed to influence academic performance is psychological capital (PsyCap). PsyCap is a set of positive psychological resources that encompasses lowerorder variables, i.e., self-efficacy, optimism, hope, and resilience (F. Luthans, Avolio, \& Youssef, 2007). PsyCap is defined as a state-like positive psychological construct that is highly involved in task performance and reaching goals. Undergraduate students use their psychological capital resources when completing a task or reaching an academic program goal. Under numerous challenging academic situations, students may need high level of self-efficacy to exert the necessary effort to complete the task. As well, optimism helps students to make positive attribution about succeeding. Finally, hope

and resilience become important psychological resources to persevere towards achieving academic goals when problems and adversity appears.

Consequently, it is important to investigate whether PsyCap could enhance students' engagement and increase students' academic performance (Siu et al., 2014). PsyCap construct has been studied by scholars over the last decade, and there is vast empirical evidence linking it to performance and positive psychological outcomes in many different cultural contexts (see F. Luthans, Youssef-Morgan, \& Avolio, 2015). B. Luthans, K. Luthans, and Jensen, (2012) found a predictive relationship between PsyCap and performance among business students. PsyCap positively predicted 
psychological well-being (Nielsen, Newman, Smyth, Hirst, \& Heilemann, 2016) and students' satisfaction with life (Riolli, Savicki, \& Richards, 2012), and was related to future academic engagement (Siu et al., 2014), achievement and happiness (Datu, King, \& Valdez, 2016; Datu \& Valdez, 2015). Moreover, the research also shows the relationship between each of the different PsyCap components, performance and psychological positive outcomes. Lane, Hall, and Lane, (2004) found that self-efficacy predicted sport studies students' performance in a statistics module. Ouweneel, Le Blanc, \& Schaufeli, (2011) found that students' self-efficacy, hope, and optimism predicted future academic engagement. These recent findings allow us to formulate our first hypothesis:

Hypothesis 1: PsyCap at time 1 will be a predictor of performance over time (time 2).

\section{PsyCap in stress events: Meaning-focused coping}

PsyCap allows students to reach goals even when they have problems and are stressed. Stress is considered a psychophysiological response originated when people think that their personal resources are unsuitable for completing a particular task successfully (Lazarus \& Folkman, 1984). Undergraduate students face a number of stressors related to their academic coursework: uncomfortable classrooms, continuous evaluation and hard exams, high pressure to obtain a degree, long and intensive days of study, etc. (Riolli et al., 2012). They need high and adaptive levels of coping strategies in order to maintain psychological well-being and performance (Gram, Jæger, Liu, Qing, \& Wu, 2013; Meneghel, 2014). In this regard, according to Folkman (2008, 2010), people adopt two different coping strategies in a demanding situation: problem-focused coping to resolve the problem (when it is considered that something can be done) and emotion- 
focused coping to directly regulate distress (when nothing can be done and it is necessary to accept the failure). For example, being awake all night to study for an exam, might be a suitable coping strategy if not too much new information has to be learnt (problem focused). On the contrary, if you have never opened the book during the semester, it might be better to go to go to bed, recover and accept the possible failure in the exam (emotion focus). Both strategies would be oriented toward reducing distress, nonetheless, according to Folkman's proposal, there is a third useful option when efforts to manage a stressful event fail: meaning-focused coping. Following our example, accepting the failure could be the first step of starting to plan how to retake the class.

Meaning-focused coping may help students to reformulate the perceived demand and to appreciate it as a challenge rather than a threat. Students draw on their own beliefs, values, and existential goals to sustain coping and psychological well-being during difficult moments. This positive reframing generates positive emotions that help them to restore the psychological resources and motivation needed to persevere through their objectives (Folkman, 2008, 2009, 2010; Lazarus, 2006). PsyCap has been related to empower students to cope up with adverse events, buffering the negative stress outcomes and boosting the positive outcomes (Riolli et al., 2012). Riolli and colleges have suggested that the mechanism for this mediating relationship is that PsyCap may be related to more positive and less negative cognitive appraisals of stress. Addressing the call to investigate this relationship, we propose that meaning-focused coping may be the psychological mechanism that mediates between PsyCap and performance.

Hypothesis 2: Meaning-focused coping will mediate the relationship between PsyCap at time 1 and performance over time (time 2). 


\section{Academic satisfaction: the role of positive emotions when adversities arise}

PsyCap and meaning-focused coping may shape a complementary cognitive and affective process related to achieving tasks and goals through positive emotions. Students may feel psychological well-being and satisfaction when they use their psychological capacities to complete their challenging tasks, especially if they are intrinsically motivated and they find real, personal meaning despite the difficulties. Bandura (2011) suggested that people make every effort to obtain satisfaction through their personal activities, especially if these activities bring meaning and purpose to their lives. It was proposed that meaning provides people with the ability to regulate emotions in daily activities (Tuazon, 2014). Furthermore, we understand that university studies play a central role in college students' lives, and we understand that university learning activities involves one's life journey during this period. Given these proposals, we hypothesize that academic satisfaction may be a mediator between "PsyCapmeaning-focused coping process" and academic performance.

Hypothesis 3: Academic satisfaction will mediate the relationship between meaning-focused coping at time 1 and performance over time (time 2).

To summarize, students use personal psychological resources to complete daily tasks and reach academic goals (Youssef-Morgan \& Luthans, 2015), persevering even under bad circumstances (Folkman, 2010). These personal resources are linked to excellence in academic performance, which might be influenced by cognitive-emotional evaluation processes such as academic satisfaction (Bandura, 2011). Identifying the path and relationships between academic performance and its psychological predictors could be used for developing evidence-based interventions to improve performance in university settings. The aim of the study was to assess the relationships between PsyCap, meaning- 
focused coping and satisfaction toward performance. The predictive path analysis model that tested the hypothesized relationships between PsyCap, meaning-focused coping, satisfaction and performance is depicted graphically in Figure 1. It was hypothesized that PsyCap would predict performance directly and also that PsyCap will predict meaning-focus coping which in turn predicts performance. Additionally, it was hypothesized that meaning-focused coping would predict satisfaction, and in turn satisfaction would predict performance as well.

INSERT FIGURE 1 OVER HERE

\section{Method}

\section{Sample and procedure}

The study was conducted at a Spanish University. Researchers gave a brief presentation of the study to participants during class time and invited them to participate on an academic well-being survey. Each student filled out a paper and pencil questionnaire. Sample comprised 682 students $(60.3 \%$ female). Participants were stratified and they belonged to the four colleges of which the University is composed: College of Humanities and Social Sciences (31.5\%), College of Law and Economics (25.1\%), School of Technology and Experimental Sciences (24\%), and College of Health Sciences (19.4\%). They belonged to 29 different undergraduate academic programs. Thereby $35.1 \%$ were studying at first year, $35.7 \%$ at second, $21.1 \%$ at third, $7 \%$ at fourth and finally $1 \%$ at fifth year. Ages ranged from 18 to 62 years old $\left(M_{\text {age }}=22.6\right.$ years; $S D=5.6)$. Finally, $84.6 \%$ were not working at the time. 


\section{Measures}

\section{Psychological capital}

To measure participants' PsyCap we adapted to the academic context the Spanish short version (12- item) of the Psychological Capital Questionnaire (PCQ-12) (Avey, Avolio, \& Luthans, 2011; F. Luthans, Avey, Clapp-Smith, \& Li, 2008). This questionnaire, distributed by Mind Garden, Inc., contains four items to measure hope, three items to measure self-efficacy, three items to measure resilience, and two to measure optimism. PsyCap is used as a higher order core construct in which these four positive psychological resources interact in a synergic way (see F. Luthans, Youssef-Morgan, \& Avolio, 2015). An example item is: "I can think of many ways to reach my current goals related to my studies". The reliability value is shown in Table 1.

\section{Meaning-focused coping strategies}

Coping strategies were assessed using The Spanish version of the Brief COPE inventory adapted to the academic context (Morán, Landero, \& González, 2010; Perczek, Carver, Price, \& Pozo-Kaderman, 2000). This questionnaire contains 28 items to measure 14 different coping reactions, including both adaptive and maladaptive. According to coping strategies literature (Folkman, 2008; Folkman \& Moskowitz, 2000) and previous research findings in factor analysis of Brief COPE inventory among Spanish undergraduate students (Meneghel, 2014), meaning-focused coping was measured using acceptance, humour and positive reframing subscales. Example items are: "I've been learning to live with it" (acceptance subscale), "I've been making jokes about it" (humour subscale), and "I've been looking for the bright side of what is happening" (positive reframing subscale). The reliability value is shown in Table 1 . 


\section{Satisfaction}

Satisfaction was measured with a four-item scale that took into consideration four main relevant aspects for university students: the university as a whole, the faculty to which they belonged, the program that they were studying at, and their professors. For each element students indicated the extent of their satisfaction on a 5-point Faces scale ranging from 1 (frowning) to 5 (smiling). An example item is: "How satisfied are you with the University?" The reliability value is shown in Table 1.

\section{Performance}

Performance was assessed by the Grade Point Average (GPA), provided by the University. It was obtained at the end of the school year around five months after the students completed the questionnaire. Consistent with the Spanish system of qualifications, GPA ranged from 5 (poor) to 10 (excellent). Because of the ethical rules of the University, at the end of the questionnaire, participants signed a consent form to obtain their permission to access to their GPA.

\section{Data analysis}

We used path modelling (Figure 1) in order to test the hypotheses and estimate both direct and indirect effects (Preacher \& Hayes, 2008). Data were analysed using path analysis program IBM SPSS Amos 21. Standardized regression coefficients were used to examine predictive paths relationships that were hypothesized (Lane et al., 2004; Meneghel, 2014). The Normed Fit Index (NFI), the Incremental Fit Index (IFI), the Tucker-Lewis Index (TLI), the Comparative Fit Index (CFI) and the Root Mean Square Error of Approximation (RMSEA) were used to assess the fit of the hypothesised model. For RMSEA values of .05 are indicative of good fit and values up to .08 
represent reasonable errors of approximation (Browne \& Cudeck, 1993). Whereas in the others indices, values of .95 or higher indicate good fit, being .90 acceptable $(\mathrm{Hu} \&$ Bentler, 1999).

Two strategies were conducted in order to mitigate problems with common method bias. First, predictor and criterion measures were obtained from different sources (Podsakoff, MacKenzie, \& Podsakoff, 2012). Thus, PsyCap, meaning-focused coping and satisfaction were obtained from self-report assessment (students), and performance was collected from an external source (GPA). Second, there was a time lag (five months) between obtaining GPA and the rest of measures.

\section{Results}

\section{Goodness of fit}

Descriptive statistics are presented in Table 1. All correlations were positive and in the expected direction. The initial hypothesized model (figure 1) showed a poor fit (NFI = $.72, \mathrm{IFI}=.72, \mathrm{TLI}=-.71, \mathrm{CFI}=.71$ and $\mathrm{RMSEA}=.32$.$) . Given the correlations found$ between the study variables (see table 1) we decided to consult the modification indices in order to improve the model goodness of fit. Based on these indices and according to the literature (F. Luthans, Avolio, Avey, \& Norman, 2007; Riolli et al., 2012), we decided to include a direct path from PsyCap to satisfaction as well as removing a direct path from meaning-focused coping to academic performance (GPA). The final hypothesized model had a good fit $(\mathrm{NFI}=.99, \mathrm{IFI}=1, \mathrm{TLI}=.98, \mathrm{CFI}=1$, and RMSEA $=.04)$.

INSERT TABLE 1 OVER HERE 


\section{Effects}

The final path model that tested hypothesized relationships between PsyCap, meaningfocused coping, satisfaction and performance is presented in Figure 2. Results showed significant relationships between PsyCap and meaning-focused coping. Meaningfocused coping significantly contributed to explain satisfaction and satisfaction significantly contributed to explain performance. PsyCap showed direct effects on performance and satisfaction.

Meaning-focused coping and satisfaction partially mediated the relationship between PsyCap and performance. We conducted bias corrected percentile method with 1000 bootstrap samples to calculate confidence intervals of indirect effects (Cheung \& Lau, 2007). We used the standardized indirect effect as an "index of mediation" (Preacher \& Hayes, 2008). The results of all the indirect effects found are presented in Table 2. Indirect effect of PsyCap on performance through meaning-focused coping and then satisfaction, was positive and significant (Indirect effect $=.041$ ). Indirect effect of PsyCap on performance through satisfaction, was positive and significant (Indirect effect $=.037$ ). The total effect of PsyCap on performance was .191 and predictor variables explained a 5\% of performance (GPA).

\section{INSERT TABLE 2 OVER HERE \\ INSERT FIGURE 2 OVER HERE}

\section{Discussion}

The aim of the study was to assess the predictive relationships between PsyCap, meaning-focused coping and satisfaction toward academic performance. The initial predictive path analysis model tested the hypothesis that PsyCap would predict 
performance directly, and also PsyCap would predict meaning-focused coping which in turn would predict performance. Additionally, it was hypothesized that meaningfocused coping would predict satisfaction, and satisfaction would predict performance as well. Results did not confirm this initial model, however, the alternative model proposed based on theoretical and statistical reasons, showed a good fit and statistically significant predictive paths. The final model confirmed most of the initial hypothesis formulated and showed interesting information regarding the role of academic satisfaction in academic performance.

These findings support our initial first hypothesis showing a positive direct relationship between PsyCap and performance over time. As in previous findings in undergraduate students' PsyCap, this study lends additional support to the capability of PsyCap as a predictor of positive psychological outcomes and excellence performance (Siu et al., 2014). Meaning-focused coping and satisfaction partially mediated the relationship between PsyCap and performance over time, supporting our third hypothesis. However, the final model did not confirm a direct effect of meaningfocused coping on performance, as it was suggested in our second hypothesis. These findings showed that meaning-focused coping strategies such acceptance, positive reappraisal, benefit finding and reminding, reordering priorities, self-regulation, and adaptive goal processes, (Folkman, 1997, 2008, 2009; Folkman \& Moskowitz, 2004) might reinforce students' PsyCap to persevere through reaching an academic goal. Students with higher levels in PsyCap would perceive the academic environment in a more positive way, assessing it as less distressing. They would perceive better challenging aspects of problems, and would be able to understand difficulties as possibilities to enhance learning and personal growth (Riolli et al., 2012). In line of Siu and colleges proposals (Siu et al., 2014), students with high development of PsyCap can 
cope better with the hindrance demands they face, which would influence positively in their success and performance.

Meaning-focused coping would help undergraduate students reaching the challenges of their study, connecting with their personal values and intrinsic motivation. Satisfaction, such a positive emotional outcome, could play a full mediating role between meaning-focused coping and academic performance. This mediation role could be an explanation of how reformulating a perceived demand to understand it as a challenge rather than a threat, may predict better performance. In this regard, this positive reframing would generate positive emotions, that might help students to restore coping resources to face demands (Folkman, 2008, 2009; Lazarus, 2006). That is, students need to be satisfied with their academic lives in order to look for the bright side in adverse situations.

The final model showed a non-hypothesised path relationship: PsyCap was directly associated with satisfaction, highlighting the importance of this variable in academic settings. PsyCap is a positive state-like based on psychological resources and involved in completing tasks successfully. For this reason, a high level of PsyCap means higher levels of happiness, satisfaction and psychological well-being (Datu et al., 2016; Datu \& Valdez, 2015; Nielsen et al., 2016; Riolli et al., 2012; Siu et al., 2014). Students feel good when they use their personal strengths and resources to complete tasks to reach academic goals. Besides, being satisfied with their studies could also reinforce the power of their psychological resources, improving excellence in their performance. Moreover, there is recent empirical evidence about how positive psychological resources increase academic satisfaction and well-being, supporting the evidence of the relevance of positive predictors on positive outcomes. Howells, Stafford, Guijt, and Breadmore (2017) found that gratitude between doctoral students 
and their supervisors have positive effects on students' psychological well-being, motivation and self-efficacy. Hanson, Trolian, Paulsen, and Pascarella (2016) found that social cooperation and collaborative learning had a significant positive effect on student's psychological well-being.

\section{Practical implications}

This study suggests multivariable predictors and mechanisms to explain and understand academic performance. Results show specifically a sequential mediated relationship between PsyCap and performance, revealing the mediating role of meaning-focused coping and satisfaction in this relationship. These theoretical links between PsyCap, meaning-focused coping, satisfaction and performance, along with the results of the present study, indicate the relevance of considering meaning-focused coping and PsyCap as two complementary psychological resources that can improve students' fulfilment.

These results provide lectures with empirical evidence to develop and implement innovative pedagogical strategies to enhance students' quality of learning and excellence performance. In order to optimize these interventions these strategies must be based on theory and research (Lane et al., 2004). The results of this study support the PsyCap literature on evidence-based interventions and institutional programs oriented to improve psychological well-being and performance in university settings (Avey, Luthans, Smith, \& Palmer, 2010; F. Luthans, Avey, Avolio, \& Peterson, 2010). However, these results suggest that adding meaning-focused coping content to PsyCap workshops (F. Luthans, Avey, Avolio, Norman, \& Combs, 2006) could be a useful strategy to reinforce the effectiveness of this positive intervention. Thus, students could attend face-to-face, small-group workshop sessions, composed of specific 
exercises designed to develop hope, optimism, self-efficacy, and resilience (PsyCap) (F. Luthans et al., 2006), and they could also train different meaning-focused coping skills. Developing personal capacity of acceptance, positive reappraisal, benefit finding, and reordering priorities and goal processes could be essential to increase levels of academic performance and psychological well-being. Positive education and positive psychology basis and literature may serve as a proper scaffolding to build these interventions, not only for extra curricula workshops but also for designing program pedagogical strategies.

\section{Limitations}

This study has several limitations which highlight important avenues for future research. First, we use self-reported data for psychological measures, which increases the risk of common method bias (Podsakoff, MacKenzie, Lee, \& Podsakoff, 2003). We consider that the use of self-reports could be justified by the nature of the constructs. However, we conducted two strategies in order to mitigate these problems with common method bias. First, predictor and criterion measures were obtained from different sources (Podsakoff et al., 2012). Thus, PsyCap, meaning-focused coping and satisfaction were obtained from self-report assessment (students), and performance was collected from an external source (GPA). On the other hand, there was a time lag (five months) between obtaining GPA and the rest of measures.

Second, our results are based on a sample from the same university. However, we found interesting results to enhance PsyCap and performance literature among students that came from different faculties and several university programs. Thus, we consider that the results need to be replicated in others universities and countries, to allow their generalizability. 
Additionally, our model explains only 5\% of students' performance. It would be interesting to reach higher levels of statistical explanation. However, academic performance is a construct influenced by several social, economic, psychological and pedagogical variables. It takes place in a complex multivariate social context, as it is education setting. Factors such as availability of resources, expectances, motivation, or previous experience, has been proposed as predictors of success in higher education (Hernández-Sánchez \& Ortega-Maldonado, 2015). Thus, previous findings in undergraduate students' PsyCap (B. Luthans et al., 2012) explained similar percentage of the variance of GPA (7\%). Additionally, previous findings in undergraduate students' coping (MacCann, Lipnevich, Burrus, \& Roberts, 2012) explained similar percentage of the variance of GPA ( $2 \%$, without considering the effects of personality factors). Finally, we consider that explaining more than $5 \%$ of students' performance is a difficult and important challenge for scholars.

\section{Conclusions and prospective}

According to our findings, PsyCap, meaning-focused coping and satisfaction have a predictor role on academic performance. Additional directions for future research include testing personal differences and factors to distinguish meaning-focused coping effectiveness with academic stress (MacCann et al., 2012; Riolli et al., 2012). Recent research has shown links between the student personality and meaning-focused coping strategies of college students. Gustems-Carnicer and Calderón (2016) found that positive reappraisal is predicted by the wisdom virtue which include personal strengths such as creativity, curiosity, perspective, judgement and love of learning (Peterson \& Seligman, 2004). Prosen and Vitulić (2016) found differences in the frequency of use of the cognitive reappraisal (meaning and positive) in different attachment styles in 
students. In this regard, qualitative research could be a useful methodology to obtain deeper information to evaluate student personality and coping mechanisms.

Finally, it would be important that additional directions for future research also include designing and testing interventions on PsyCap and meaning-focused coping at the academic setting. Students need excellence performance in order to get better employability. They need to learn technical knowledge and develop better learning strategies. But they also need to increase their psychological capacities and skills related to face daily life with emotional intelligence. Higher education institutions should address this real need, and scholars and lecturers could support them with evidencebased interventions. The better the interventions are, the better the students' quality of life will be.

\section{Acknowledgements}

We wish to thank the reviewers for their fruitful comments and feedback. We feel that they improved the manuscript.

\section{References}

Avey, J. B., Avolio, B. J., \& Luthans, F. (2011). Experimentally analyzing the impact of leader positivity on follower positivity and performance. Leadership Quarterly, 22(2), 282-294. http://doi.org/10.1016/j.leaqua.2011.02.004

Avey, J. B., Luthans, F., Smith, R. M., \& Palmer, N. F. (2010). Impact of positive psychological capital on employee well-being over time. Journal of Occupational Health Psychology, 15(1), 17-28. http://doi.org/10.1037/a0016998

Bandura, A. (2011). A Social Cognitive perspective on Positive Psychology. Revista de Psicología Social, 26(1), 7-20. http://doi.org/10.1174/021347411794078444

Browne, M. W., \& Cudeck, R. (1993). Alternative ways of assessing model fit. In K. A. Bollen \& J. S. Long (Eds.), Testing structural equations models (pp. 136-162). Newbury Park, CA: Sage.

Cheung, G. W., \& Lau, R. S. (2007). Testing Mediation and Suppression Effects of Latent Variables. Organizational Research Methods, 11(2), 296-325. JOUR. 
http://doi.org/10.1177/1094428107300343

Datu, J. A. D., King, R. B., \& Valdez, J. P. M. (2016). Psychological capital bolsters motivation, engagement, and achievement: Cross-sectional and longitudinal studies. The Journal of Positive Psychology, 1-11. http://doi.org/10.1080/17439760.2016.1257056

Datu, J. A. D., \& Valdez, J. P. M. (2015). Psychological Capital Predicts Academic Engagement and Well-Being in Filipino High School Students. The Asia-Pacific Education Researcher, (2001). http://doi.org/10.1007/s40299-015-0254-1

Folkman, S. (1997). Positive psychological states and coping with severe stress. Social Science and Medicine, 45(8), 1207-1221. http://doi.org/10.1016/S02779536(97)00040-3

Folkman, S. (2008). The case for positive emotions in the stress process. Anxiety, Stress, and Coping, 21(1), 3-14. http://doi.org/10.1080/10615800701740457

Folkman, S. (2009). Commentary on the Special Section "Theory-Based Approaches to Stress and Coping." European Psychologist, 14(1), 72-77. http://doi.org/10.1027/1016-9040.14.1.72

Folkman, S. (2010). Stress, coping, and hope. Psycho-Oncology, 19(9), 901-8. http://doi.org/10.1002/pon.1836

Folkman, S., \& Moskowitz, J. T. (2000). Positive affect and the other side of coping. American Psychologist, 55(6), 647-654. http://doi.org/10.1037//0003066X.55.6.647

Folkman, S., \& Moskowitz, J. T. (2004). Coping: pitfalls and promise. Annual Review of Psychology, 55, 745-74. http://doi.org/10.1146/annurev.psych.55.090902.141456

Fugate, M., Kinicki, A. J., \& Ashforth, B. E. (2004). Employability: A psycho-social construct, its dimensions, and applications. Journal of Vocational Behavior, 65(1), 14-38. http://doi.org/10.1016/j.jvb.2003.10.005

Gram, M., Jæger, K., Liu, J., Qing, L., \& Wu, X. (2013). Chinese students making sense of problem-based learning and Western teaching - pitfalls and coping strategies. Teaching in Higher Education, 18(7), 761-772. JOUR. http://doi.org/10.1080/13562517.2013.836096

Gustems-Carnicer, J., \& Calderón, C. (2016). Virtues and character strengths related to approach coping strategies of college students. Social Psychology of Education, 19(1), 77-95. http://doi.org/10.1007/s11218-015-9305-y

Hanson, J. M., Trolian, T. L., Paulsen, M. B., \& Pascarella, E. T. (2016). Evaluating the influence of peer learning on psychological well-being. Teaching in Higher Education, 21(2), 191-206. http://doi.org/10.1080/13562517.2015.1136274 
Hernández-Sánchez, A. M., \& Ortega-Maldonado, A. (2015). Hacia la personalización del e-Learning: La afectividad y su repercusión en el bienestar subjetivo. Revista Lasallista de Investigacion, 12(2), 194-203.

Howells, K., Stafford, K., Guijt, R., \& Breadmore, M. (2017). The role of gratitude in enhancing the relationship between doctoral research students and their supervisors. Teaching in Higher Education, 1-18. JOUR. http://doi.org/10.1080/13562517.2016.1273212

Hu, L., \& Bentler, P. M. (1999). Cutoff criteria for fit indexes in covariance structure analysis: Conventional criteria versus new alternatives. Structural Equation Modeling: A Multidisciplinary Journal, 6(1), 1-55. JOUR. http://doi.org/10.1080/10705519909540118

Lane, A. M., Hall, R., \& Lane, J. (2004). Self-efficacy and statistics performance among Sport Studies students. Teaching in Higher Education, 9(4), 435-448. http://doi.org/10.1080/1356251042000252372

Lazarus, R. S. (2006). Emotions and interpersonal relationships: toward a personcentered conceptualization of emotions and coping. Journal of Personality, 74(1), 9-46. http://doi.org/10.1111/j.1467-6494.2005.00368.x

Lazarus, R. S., \& Folkman, S. (1984). Stress, Appraisal, and Coping. New York: Springer.

Luthans, B. C., Luthans, K. W., \& Jensen, S. M. (2012). The Impact of Business School Students' Psychological Capital on Academic Performance. Journal of Education for Business, 87(October), 253-259. http://doi.org/10.1080/08832323.2011.609844

Luthans, F., Avey, J. B., Avolio, B. J., Norman, S. M., \& Combs, G. M. (2006). Psychological capital development: toward a micro-intervention. Journal of Organizational Behavior, 27, 387-393.

Luthans, F., Avey, J. B., Avolio, B. J., \& Peterson, S. J. (2010). The Development and Resulting Performance Impact of Positive Psychological Capital. Human Resource Development Quarterly, 21(1), 41-67. http://doi.org/10.1002/hrdq

Luthans, F., Avey, J. B., Clapp-Smith, R., \& Li, W. (2008). More evidence on the value of Chinese workers' psychological capital: A potentially unlimited competitive resource? The International Journal of Human Resource Management, 19(5), 818827. http://doi.org/10.1080/09585190801991194

Luthans, F., Avolio, B. J., Avey, J. B., \& Norman, S. M. (2007). Positive Psychological Capital: Measurement and Relationship with Performance and Satisfaction. Personnel Psychology, 60, 541-572.

Luthans, F., Avolio, B. J., \& Youssef, C. M. (2007). Psychological Capital: Developing the Human Competitive Edge. Oxford University Press. 
Luthans, F., Youssef-Morgan, C. M., \& Avolio, B. J. (2015). Psychological Capital and Beyond. New York: Oxford University Press.

MacCann, C., Lipnevich, A. a., Burrus, J., \& Roberts, R. D. (2012). The best years of our lives? Coping with stress predicts school grades, life satisfaction, and feelings about high school. Learning and Individual Differences, 22(2), 235-241. http://doi.org/10.1016/j.lindif.2011.08.004

Meneghel, I. (2014). An Integrated Analysis of Resilience: How to Achieve Positive Outgrowths. Universitat Jaume I de Castellón.

Morán, C., Landero, R., \& González, M. T. (2010). COPE-28: A Psychometric Analysis of the Spanish Version of the Brief COPE. Universitas Psychologica, 9(2), 543552.

Nielsen, I., Newman, A., Smyth, R., Hirst, G., \& Heilemann, B. (2016). The influence of instructor support, family support and psychological capital on the well-being of postgraduate students: a moderated mediation model. Studies in Higher Education, Advance on(February). http://doi.org/10.1080/03075079.2015.1135116

Ouweneel, E., Le Blanc, P. M., \& Schaufeli, W. B. (2011). Flourishing students: A longitudinal study on positive emotions, personal resources, and study engagement. The Journal of Positive Psychology, 6(2), 142-153. http://doi.org/10.1080/17439760.2011.558847

Perczek, R., Carver, C. S., Price, A. A., \& Pozo-Kaderman, C. (2000). Coping, Mood, and Aspects of Personality in Spanish Translation and Evidence of Convergence With English Versions. Journal of Personality Assessment, 74(1), 63-87.

Peterson, C., \& Seligman, M. E. P. (2004). Character Strengths and Virtues. Oxord University Press. http://doi.org/313971759

Podsakoff, P. M., MacKenzie, S. B., Lee, J.-Y., \& Podsakoff, N. P. (2003). Common method biases in behavioral research: A critical review of the literature and recommended remedies. Journal of Applied Psychology. JOUR PMID 14516251, Podsakoff, Philip M.: Department of Management, Kelley School of Business, Indiana University, 1309 East Tenth Street, Bloomington, IN, US, 47405-1701, podsakof@indiana.edu: American Psychological Association. http://doi.org/10.1037/0021-9010.88.5.879

Podsakoff, P. M., MacKenzie, S. B., \& Podsakoff, N. P. (2012). Sources of Method Bias in Social Science Research and Recommendations on How to Control It. Annual Review of Psychology, 63, 539-569. http://doi.org/10.1146/annurev-psych120710-100452

Preacher, K. J., \& Hayes, A. F. (2008). Asymptotic and resampling strategies for assessing and comparing indirect effects in multiple mediator models. Behavior 
Research Methods, 40(3), 879-891. article. http://doi.org/10.3758/BRM.40.3.879

Prosen, S., \& Vitulić, H. S. (2016). Emotion Regulation and Coping Strategies in Pedagogical Students with Different Attachment Styles. Japanese Psychological Research, 58(4), 355-366. http://doi.org/10.1111/jpr.12130

Riolli, L., Savicki, V., \& Richards, J. (2012). Psychological Capital as a Buffer to Student Stress. $\quad$ Psychology, $\quad 3(12), \quad 1202-1207$. http://doi.org/10.4236/psych.2012.312A178

Siu, O. L., Bakker, A. B., \& Jiang, X. (2014). Psychological Capital Among University Students: Relationships with Study Engagement and Intrinsic Motivation. Journal of Happiness Studies, 15(4), 979-994. http://doi.org/10.1007/s10902-013-9459-2

Tuazon, G. . F. M. (2014). Applying Meaning at Work: Effective Use of Meaning in the Workplace. International Journal of Existential Psychology and Psychotherapy, 5, 157-169.

Youssef-Morgan, C. M., \& Luthans, F. (2015). Psychological Capital and Well-being. Stress and Health, 31(3), 180-188. http://doi.org/10.1002/smi.2623 
Table 1. Descriptive statistics for Psychological capital, meaning-focused coping, satisfaction and performance.

\begin{tabular}{lcccccc}
\hline & Mean & SD & 1 & 2 & 3 & 4 \\
\hline (1) Psychological Capital (T1) & 4.05 & 0.82 & $(.77)$ & & \\
(2) Meaning-focused coping (T1) & 1.73 & 0.56 & .39 & $(.68)$ & \\
(3) Satisfaction (T1) & 3.77 & 0.67 & .36 & .21 & $(.71)$ \\
(4) Performance (GPA) (T1) & 7.01 & 0.76 & .19 & .13 & .17 & - \\
\hline
\end{tabular}

Notes: $\mathrm{N}=682$. All correlations higher than .10 are significant at $p<.01$. Cronbach's $\alpha$ reliability estimates are listed in the diagonal in parentheses. 
Table 2. Indirect effects.

\begin{tabular}{lcccc}
\hline Paths & $\begin{array}{c}\text { Indirect } \\
\text { effect }\end{array}$ & SE & \multicolumn{2}{c}{95 Confidence Interval } \\
\cline { 4 - 5 } & & & Lower Bound & Upper Bound \\
\hline PsyCap (T1) $\rightarrow$ Satisfaction (T1) & .031 & .040 & .002 & .065 \\
PsyCap (T1) $\rightarrow$ Performance (T2) & .041 & .005 & .015 & .072 \\
Meaning -focused coping (T1) $\rightarrow$ Performance (T2) & .009 & .029 & .001 & .025 \\
\hline Notes: $\mathrm{N}=682$. Standardized path coefficients. *** $<<.001$ & & & &
\end{tabular}


Figure 1. Initial model hypothesized.

TIME 1

TIME 2

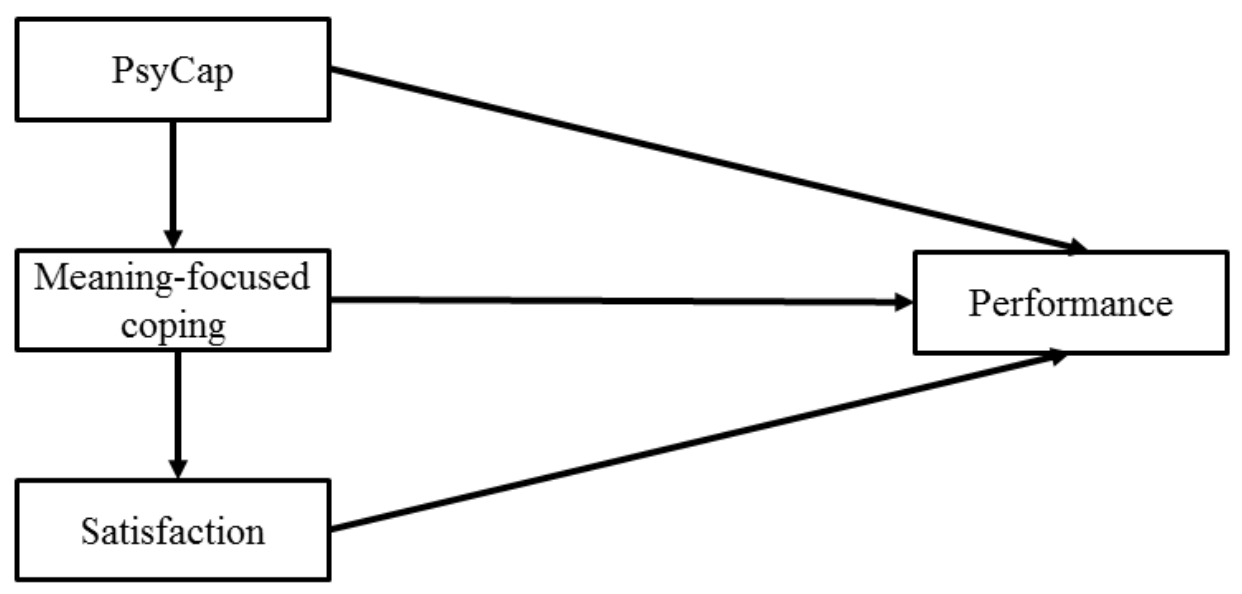


Figure 2. Path model to investigate predictive relationships between PsyCap, Meaningfocused coping, satisfaction and performance among undergraduate students $(N=682)$.

TIME 1

TIME 2

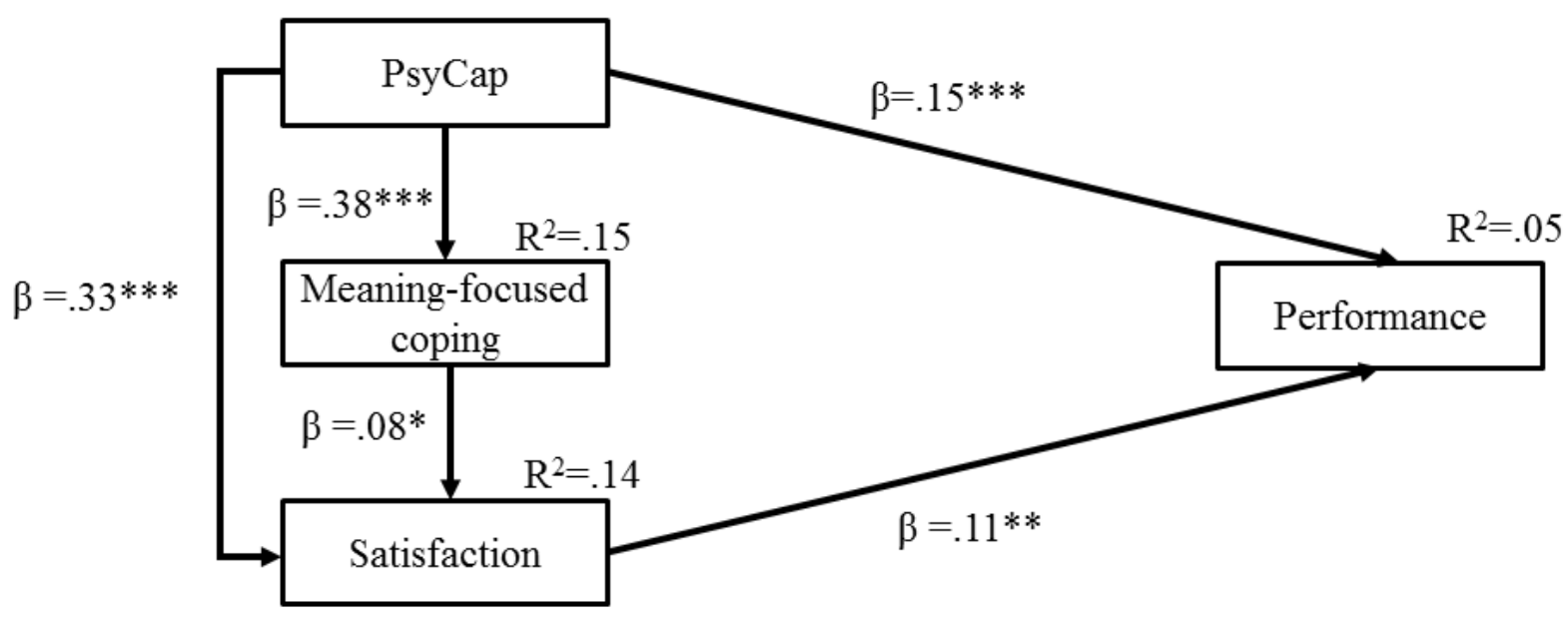

Notes: $* p<.05 ; * * p<.01 ; * * * p<.001$. 